\title{
ČLÁNKY
}

\section{The Rule of Law Framework and its Effectiveness}

\author{
Štěpán Paulík ${ }^{*}$
}

\begin{abstract}
The article gathers information about the Rule of Law Framework and analyzes the Rule of Law Framework and its implementation. It starts by introducing the Framework itself. It further maps out its implementation via the Recommendations made against Poland. The Recommendations are set within their context, and their reception by Poland follows. Building on the experience, the European Commission opened a discussion on the future of the Framework and its potential improvement. The discussion is touched upon in the article as well. The article analyzes the effectiveness of the Framework in a case study in Poland. It concludes that the Framework was ineffective with regard to achieving its three functions.
\end{abstract}

\section{Keywords}

Rule of Law; Rule of Law Framework; Article 7 TEU; Poland; Foundational Values.

\section{Introduction}

Art. 2 Treaty on the European Union ('TEU') stipulates that the European Union ('EU') is founded on the values of (...) democracy, the rule of law and respect for human rights. The rule of law has become of central importance as it is a prerequisite for effective application of EU law and for mutual trust among the Member states. ${ }^{1}$ The recent affairs, especially in Poland and Hungary, have triggered concerns about the presumption of adherence of all Member states to the rule of law and about the EU 's ability to enforce the values. The EU wields several instruments to enforce the Art. 2 TEU values: Art. 7 TEU procedure, the infringement procedure, and, more recent additions, the Rule of Law Framework and the Annual Rule of Law Cycle. They are together

\footnotetext{
* Štěpán Paulík, student, Právnická fakulta, Masarykova univerzita, Brno / Student, Faculty of Law, Masaryk University, Brno, Czech Republic / E-mail: 458801@mail.muni.cz

1 "Strenghtening the Rule of Law within the Union: A blueprint for action" (Communication from the commission to the European Parliament, the European Council, and the Council) COM(2019) 343 final. European Commission [online]. 2019, p. 1 [cit. 22. 2. 2020]. Available at: https://eur-lex.europa.eu/ legal-content/EN/ALL/?uri=COM\%3A2019\%3A343\%3AFIN
} 
referred to as a 'EU rule of law toolbox'. ${ }^{2}$ This article analyzes and discusses the Rule of Law Framework because the first two instruments of enforcement have enjoyed ample attention, ${ }^{3}$ whereas the Framework has gone more or less unnoticed ${ }^{4}$ and the last one has been put to use very recently and only once. ${ }^{5}$

The aim of this article is to analyze the Framework and its implementation. Building on the analysis, an assessment of the Framework's effectiveness in the form of a case study follows.

The Framework is firstly comprehensively introduced and analyzed in Part 2. Part 3 goes through the state of the art of legal scholarship concerning the Framework. Building on the preceding analysis, an overview of how the Framework was put into practice follows in Part 4. In that part, all Recommendations issued on the basis of the Framework are introduced and discussed. Part 5 contains a case study of Poland. The aim of the case study is to assess the effectiveness of the Framework. Part 6 concludes.

\section{The Rule of Law Framework and the State of the Art}

The European Commission came up with a new mechanism to enforce rule of law, the new EU Framework to strengthen the Rule of Law ('Rule of Law Framework' or 'Framework') to complement its rule of law toolbox. The Commission announced the Framework in the communication to the European Parliament and Council on 11 March $2014 .^{6}$

The Rule of Law Framework's objective is to 'ensure an effective and coherent protection of the rule of law (...) where there is a systemic threat to the rule of law.'

While the Framework leaves the definition of the concept of rule of law open, it provides a non-exhaustive list of six principles that define its core meaning. Those principles

2 L. Pech offers a chronological overview of all the rule of law enforcement mechanisms that the EU wields currently. PECH, L. The Rule of Law in the EU: The Evolution of the Treaty Framework and Rule of Law Toolbox. Reconnect Working Papers [online]. 2020 [cit. 16. 10. 2020]. Available at: https://www. ssrn.com/abstract $=3608661$

3 BESSELINK, L. The Bite, the Bark, and the Howl: Article 7 TEU and the Rule of Law Initiatives. In: The Enforcement of EU Law and Values: Ensuring Member States' Compliance. Oxford: Oxford University Press, 2017; GORMLEY, L. W. Infringement Proceedings. In: The Enforcement of EU Law and Values: Ensuring Member States' Compliance. Oxford: Oxford University Press, 2017; WENNERÅS, P. Making effective use of Article 260 TFEU. In: The Enforcement of EU Law and Values: Ensuring Member States' Compliance. Oxford: Oxford University Press, 2017; PECH, op. cit., 2020.

4 Apart from the fragmentary contributions summarized in the chapter Doctrinal reflection.

5 Too Little, Too Late. Verfassungsblog [online]. 2. 10. 2020 [cit. 26. 11. 2020]. Available at: https://verfassungsblog.de/too-little-too-late/

6 "A new EU Framework to strenghen the Rule of law" (Communication from the Commission to the European Parliament and the Council) $\operatorname{COM}(2014) 158$ final. European Commission [online]. 2014 [cit. 13. 2. 2020]. Available at: https://eur-lex.europa.eu/legal-content/EN/ ALL/?uri=CELEX:52014DC0158 
include legality, which implies a transparent, accountable, democratic and pluralistic process for enacting laws; legal certainty; prohibition of arbitrariness of the executive powers; independent and impartial courts; effective judicial review including respect for fundamental rights; and equality before the law. ${ }^{7}$ The rule of law is juxtaposed to the principles of democracy and respect for fundamental rights. ${ }^{8}$ The listed principles suggest adherence to the thin notion of the concept of rule of law by the Commission. ${ }^{9}$ The inclination towards the thin notion of the rule of law is rather advisable, for the thick notion of rule of law has been criticized for blurring the lines between the concept of rule of law and the good law (including democracy etc.), ${ }^{10}$ thus opening up the Commission for criticism of enforcing other values contained in Art. 2 TEU under the auspices of the rule of law. Be it as it may, the Commission's definition reflects the European consensus on the content of rule of law that the Reconnect scholars suggest there is in Europe. ${ }^{11}$

The Framework admits that there currently exists a gap in the effective mechanisms that the EU wields against the systemic threat to the rule of law. While Art. 258 TFEU infringement proceedings may be ineffective for a plethora of reasons, the Framework expressly points out the necessity of finding a breach of a specific provision of EU law. And although Art. 7 TEU procedure contains both preventive and sanctioning mechanisms ${ }^{12}$ the threshold for activating, especially the latter, is very high. ${ }^{13}$ The Framework thus fills a gap concerning constitutional crises where there is a systemic threat to the rule of law without the existence of a 'clear risk of serious breach' or 'serious and persistent breach' as required by Art. 7 TEU.

7 Ibid., p. 4.

8 Perhaps most clearly in the new Rule of Law Report. See COMMUNICATION FROM THE COMMISSION TO THE EU ROPEAN PARLIAMENT, THE COUNCIL, THE EU ROPEAN ECONOMIC AND SOCIAL COMMITTEE AND THE COMMITTEE OF THE REGIONS 2020 Rule of Law Report The rule of law situation in the European Union COM(2020) 580 final. European Commission [online]. 30. 9. 2020.

9 The thin concepts of rule of law limit themselves to formal properties of laws and legal institutions, that are purported to constitute the rule of law. The thick concepts of rule of law require substantive elements from a larger vision of a good society and polity - democratic, free-market, human rights respecting, or some such - to be present. KRYGIER, M. Rule of Law (and Rechtsstaat). UNSW Law Research Paper No. 2013-52 [online]. 2013, p. 8 [cit. 20. 3. 2020]. Available at: https://papers.ssrn.com/ sol3/papers.cfm?abstract_id $=2311874$

10 Joseph Raz clearly points out that rule of law should not be confused with other virtues such as democracy, respect for human rights, human dignity and alike. RAZ, J. The authority of law: Essays on law and morality. Oxford University Press, 1979, p. 211.

11 PECH, L. et al. Meaning and Scope of the EU Rule of Law. Reconnect Deliverables, 2020, pp. 38-42.

12 Art. 7 TEU enforces compliance with the values enumerated in Art. 2 TEU. It has a three part structure constiting of the determination of "a clear risk of a serious breach" "a serious and persistent breach", and imposition of sanctions in case of the determiantion of the latter. The threshold for determination of "a serious and persistent breach" is unanimity in the European Council. BESSELINK, 2017, op. cit., pp. 129-133.

13 KOCHENOV, D. and L. PECH. Better Late than Never? On the European Commission's Rule of Law Framework and its First Activation. Journal of Common Market Studies, 2016, no. 5, pp. 1065-1066. 
The Framework is a preventative mechanism that precedes triggering Art. 7 TEU seeking to prevent the emergence of a threat to the rule of law that could develop into a 'clear risk of a serious breach'. This objective underlines the whole mechanism.

The Commission is the body to trigger the procedure under the Framework. At what point should the Commission trigger the Framework procedure? The Framework is 'not designed to be triggered by individual breaches of fundamental rights or by a miscarriage of justice'; it can only be triggered against threats to the rule of law which are of a systemic nature. The Framework builds on the presumption that Member states comply with the rule of law, thus individual breaches of the principle do not fall within the scope of the Framework. ${ }^{14}$

The Commission hints that threats are considered to be systemic when 'national "rule of law safeguards" do not seem capable of effectively addressing those threats.' On this basis, Sadurski argues that the collapse or absence of effective self-correction mechanisms are symptoms and/or cause of a systemic threat. ${ }^{15}$

I, for one, do not see a clear relationship between systemic threats to the rule of law and a clear risk of a serious breach under Art. 7 TEU. Once the rule of law is systematically threatened in the way the Commission describes it, i.e. the domestic authorities are incapable of addressing those threats, then it is reasonable to suppose that there is also a clear risk of a serious breach of the rule of law. There are hardly more risks of a serious breach than the inability of domestic institutions to address the severe situation.

Once the Framework is triggered, a three-stage process of a dialogue with the Member state concerned ensues. First, the Commission assesses whether there are clear indications of a systemic threat to the rule of law by collecting and examining all relevant information. As a result of the assessment, if the Commission becomes of the opinion that there is such a threat, it sends the Member state a 'rule of law opinion' substantiating its concerns. A back-and-forth play of responses follows. Second, if the Member state fails to resolve the situation and the systemic threat to the rule of law remains, the Commission may issue a 'rule of law recommendation' in which it will indicate the causes of the threat and a recommended action to address them within a fixed time limit. Third, the Commission will monitor the compliance of the Member state with the recommendation. If there is no satisfactory resolution, the Commission may have the recourse to one of the mechanisms set out in Art. 7 TEU. ${ }^{16}$

14 BOGDANDY, A. V., C. ANTPOHLER and M. IOANNIDIS. Protecting EU Values: Reverse Solange and the Rule of Law Framework. In: The Enforcement of EU Law and Values: Ensuring Member States' Compliance. Oxford: Oxford University Press, 2017, p. 226.

15 SADURSKI, W. Poland's Constitutional Breakdown. Oxford, New York: Oxford University Press, 2019, p. 218.

$16 \operatorname{COM}(2014) 158$ final (n 1), pp. 7-8. 


\section{State of the Art}

Now that the Framework has been introduced, I turn to the state of the art of legal scholarship dedicated to the Framework. The literature on the Rule of Law Framework is rather scarce. Moreover, all but one articles precede the latter 2016 and both 2017 activations of the Framework by the Commission against Poland. Hence only the Framework itself and its first activation have so far mainly been taken into account. Hence a more detailed and in-depth analysis of the effectiveness of the Framework is desirable.

In 2016, Kochenov and Pech assessed the Rule of Law Framework. Although a step in the right direction, the authors found a couple of shortcomings. First, because a structured dialogue between the Commission and the Member state concerned took centre stage, Kochenov and Pech doubt the presumption that a discursive approach will be effective against countries where the ruling elite had made a deliberate choice to implement measures clearly in breach of EU values. Second, adding a legally non-binding step before the non-automatic recourse to Art. 7 increases the likelihood of protracted discussion. Protracted discussion may only allow the recalcitrant government to entrench and further legal measures that are incompatible with the Art. 2 TEU values, thus leading to ineffective outcomes. Both authors are aware that the validity of their criticism can be tested against time. The Commission's double standards against Poland and Hungary weren't left uncriticized either. ${ }^{17}$

Bogdandy, Antpohler, and Ioannidis also left the question of the effectiveness of the Framework up for the test of time. On the one hand, the authors expressed cautious optimism due to the potential to exert 'considerable political pressure' on the Member state via activation of the Framework. On the other hand, the authors remain sceptical regarding the dominant role of the Commission. The effectiveness could be undermined by the Commission's double standards and its politicizations, both of which had been used as a counterargument by Eurosceptics against its Rule of Law initiatives. That is why the authors suggest establishing an independent Systemic Deficiency Committee that would replace the Commission. ${ }^{18}$

The only author to take into account all four recommendations was Sadurski. After an analysis of the Recommendations, Sadurski concludes that the only substantive result of the implementation of the Framework was the equalization of the lowered retirement age from 67 to 65 for both genders. Other changes were cosmetic, or there were in the majority of cases no changes at all. ${ }^{19}$ Yet his analysis does not differentiate between the functions the Framework could serve and does not offer an in-depth analysis of its effects.

17 KOCHENOV, PECH, 2016, op. cit., pp. 1066-1067.

18 BOGDANDY, ANTPOHLER, IOANNIDIS, 2017, op. cit., pp. 228-229.

19 SADURSKI, 2019, op. cit., p. 222. 


\section{The Implementation of the Framework}

An overview of how the Framework was put into practice ensues. There have so far been made four recommendations on the basis of the Framework. All four were aimed at Poland.

\subsection{The First Recommendation}

The Commission first opened a dialogue with Poland in December 2015. Following an exchange of letters, the Commission adopted the first Rule of Law Opinion on 1 June 2016. Because the Polish government did not comply, the Commission adopted the Rule of Law Recommendation on 27 July $2016 .{ }^{20}$

Prawo i Sprawiedliwosc ('PiS'), immediately after coming into power in 2015, engaged in court packing the Constitutional Tribunal ('CT'). The previous government had, in October 2015, before the election, appointed five judges, 2 of which were appointed unlawfully as they had been appointed prematurely. PiS disregarded the appointment of all five judges, including the lawfully appointed trio, and in December, appointed its five judges. The three 'December' judges improper appointment and the law stipulating that they replace the three 'October' judges were on 3 December 2015 and 9 December respectively declared unconstitutional by the $\mathrm{CT} .^{21}$

On top of the court-packing, PiS bombarded the CT with numerous amendments of the statute on the CT. The government tried to approbate its meddling with the three judges and to remove the President and Vice-President of the CT. The CT struck down the whole statute on the CT in its judgment from 9 March 2016. ${ }^{22}$ The government's reaction was not to publish the judgment, a condition for its bindingness, arguing that it was delivered in violation of the new statute. ${ }^{23}$

The government went to re-enact similar amendments in the statute on the CT from 22 July 2016. Notwithstanding that there was a slight improvement of the law on the CT between the 2015 amendment and the new 2016 law following, the statute was on 11 August 2016 found unconstitutional by the CT. ${ }^{24}$

The first Recommendation addressed the invalidity of the appointment of the 'December' judges, the 'October' judges not taking up their office, the lack of publication and implementation of the 9 March 2016 Constitutional Tribunal judgment concerning the amendment of the law on the CT and all the consequent decisions, the 22 July 2016 law on the CT,

20 Commission Recommendation (EU) 2016/1374 regarding the rule of law in Poland. European Commission [online]. 2016

21 For more detailed description see SADURSKI, 2019, op. cit., pp. 61-65.

22 Ibid., pp. 70-72.

23 Ibid., pp. 75-77.

24 Hence after the first recommendation had been issued. Ibid., p. 71. 
the lack of effective constitutional review concerning other major legal changes. ${ }^{25}$ The Commission recommended that the Polish authorities:

- Implement the judgments of the CT of 3 and 9 December, which require that the 'November' judges take up their position and that the 'December' judges nominated by PiS without a valid legal basis do not take up their position.

- Publish and implement the judgments of the CT of 9 March 2016 and its subsequent judgments, ensure that the publishment is automatic.

- Ensure the effectiveness of the CT's constitutional review is not undermined.

- Refrains from actions and public statements that could undermine the legitimacy and efficiency of the CT. ${ }^{26}$

The Commission set a three months time limit to implement the recommended action. In sum, the first Recommendation addressed mainly the attack on the CT while leaving the door open for widening the scope by including the ineffectiveness of constitutional review of many other laws.

As Sadurski rightly notices, the Polish government waited until the last day of the limit with its response to the first Recommendation. ${ }^{27}$ The response struck a passive-aggressive note by indicating that the Polish government 'welcomes openly any suggestions on how to improve the work of the constitutional court', while simultaneously accusing the Commission of not adhering the principles of 'objectivism, or respect for sovereignty, subsidiarity, and national identity' and of basing its 'unwarranted' conclusions on incorrect assumptions and incomplete knowledge of the Polish legal system. ${ }^{28}$ It claimed that the ongoing political dispute about the rules on the CT did not amount to a systemic threat without providing any grounds for such a claim. The Polish government deemed the first Recommendation groundless. ${ }^{29}$

25 New media law, Civil Service Act, amendments of the Law on the Police, the Law on the national Council of Media, and new anti-terrosim law.

26 Commission Recommendation (EU) 2016/1374, para. 74.

27 SADURSKI, 2019, op. cit., p. 2019.

28 Kochenov and Bard list four strategies of authoritarian populists to deflect European criticism. Among there are invocation of national sovereignty when undermining national institutions, the second is appeal to constitutional identity. They are both obviously present in the Polish government's answer. KOCHENOV, D. and P. BARD. Rule of Law Crisis in the New Member States of the EU: The Pitfalls of Overemphasising Enforcement. Reconnect Working Papers [online]. 2018, pp. 9-12 [cit. 16. 10. 2020]. Available at: https://papers.ssrn.com/abstract $=3221240$

29 MFA statement on the Polish government's response to Commission Recommendation of 27. 7. 2016. Ministerstwo Spraw Zagranicznych [online]. [cit. 18.2.2020]. Available at: https://www.msz.gov.pl/en/p/ $\mathrm{msz}$ _en/news/mfa_statement_on_the_polish_government_s_response_to_commission_recommendation_of_27_07_2016 [The Polish Ministry of Foreign Affairs webpage underwent major reconstruction between the time I submitted the article and its publication. None of the links works now, and the articles with the responses have not been transferred to the new webpage. They were not archived either. Hence, the Polish government's responses are now unavailable - auth. comment] 
Not only did the Polish government not substantiate its counterarguments in the response, but it is also plainly wrong that a non-binding dialogue-based recommendation may in any way imperil the sovereignty or national identity of the Polish Republic.

\subsection{The Second Recommendation}

The second Rule of Law Recommendation ensued shortly after the first when it was clear that the Polish government would stick to its guns. The Commission issued a second complementary Recommendation on 21 December 2016. ${ }^{30}$

At this point, it is important to stress out that the original communication did not account for the multiplicity of recommendations. Only one is presumed by the communication before the triggering of Art. 7 TEU is justified. While the Commission's second triggering of the Framework may have easily been turned against it, it was not, as will be shown later, in the responses of the Polish government to the Recommendations.

The Commission repeated its concerns about the lack of implementation of the judgments finding the appointment of the 'December' judges unconstitutional and the inaction of the Polish government about the appointment of the 'October' judges. The Polish government still refused to publish and implement the 9 March 2016 and onwards decision(s) of the CT on the basis that it had the power to review the lawfulness of the judgments. ${ }^{31}$

The combined effect of various measures on the effectiveness of the constitutional review remained. Although the Polish government made some changes to the law on the CT and cosmetically improved the situation, it failed to acknowledge and implement the majority of the concerns of the Commission from the first Recommendation. Interestingly, the Polish government amended the law instead of publishing an 11 August 2016 CT judgment which had declared some of the provisions of the law on the CT unconstitutional. The Polish government had, in the meantime, introduced a new batch of worrisome measures. The law on the status of judges gave the President of the Republic the power to initiate disciplinary proceedings against CT judges, the government created an incentive for CT judges to retire early and introduced some new requirements of the judges of the CT, including a declaration of assets and declaration on the activity of their spouses. The CT was internally reorganized by creating two new chambers. The majority of the provisions entered into force the day after their publishment without any vacatio legis. ${ }^{32}$

As a consequence of these changes, new legislative acts, often passed through the accelerated legislative procedure, could not be effectively reviewed. The laws not effectively reviewed by the CT include the law on the Ombudsman, on the Public Prosecution

30 Commission Recommendation (EU) 2017/146 regarding the rule of law in Poland complementary to Recommendation (EU) 2016/1374. European Commission [online]. 2016.

31 Ibid., para. 15.

32 Ibid., paras. 32-33; SADURSKI, 2019, op. cit., p. 33. 
office, the Civil Service Act, the budgetary law on top of the laws mentioned in the first Recommendation. A number of them raise concerns on their own about the rule of law and fundamental rights. The ineffectiveness of constitutional review was addressed by the Commission.

The Commission lastly addressed the rochade on the position of the President of the CT. The new Law on the organization and proceedings created a position of an acting President of the CT tasked with temporarily carrying out the role of the President of the CT, hence effectively negating the function of the Vice-President. The acting President of the CT is appointed by the President of the Republic without the requirement of the nomination by the CT's general assembly. ${ }^{33}$ Moreover, the selection procedure of the President of the CT had been amended so that the participation of the unlawfully elected 'December' judges was required.

The changes were immediately put into practice so that PiS-selected judge Julia Przyłębska had first been appointed as the acting President. Only to be later selected as the President of the CT by a General Assembly with only six judges present. What's more, three of the present judges were the unconstitutionally appointed 'December' judges, plus the whole procedure was mired in irregularities. ${ }^{34}$

The Commission dedicated more space and effort to finding the 'systemic threat' than in the first Recommendation. On top of the recommended actions that had been made in the first Recommendation, the Commission recommended that the Polish authorities in the 2 months limit:

- Ensure that the CT can review the constitutionality of the law on the status of judges, the law on the organization and proceedings and the implementing law, and its decisions are published and implemented fully,

- Ensure that no appointment of the President of the CT takes place as long as the three unlawfully appointed judges to participate and as long as the judgments of the CT on the constitutionality of the new laws had not been published and implemented fully,

- Ensure that the Vice-President, not the acting President temporarily carries out the function of the President of the CT. ${ }^{35}$

As the crisis of the CT worsened from the first Recommendation, the second Recommendation again addressed mainly the changes made to the CT, other laws being only implied under the lack of effective constitutional review.

33 As required when selecting the President of the CT.

34 For more detailed description of the whole election procedure see SADURSKI, 2019, op. cit., pp. 65-66.

35 Commission Recommendation (EU) 2017/146 regarding the rule of law in Poland complementary to Recommendation (EU) 2016/1374. European Commission [online]. 2016, p. 62. 
The Polish government yet again waited until the last day of the limit for its response to the second recommendation. It insisted that all the changes to the CT and the replacement of the President were in line with the European standards and made in order for the CT to operate properly. The government, on top of reiterating its accusations, sharpened its tone by singling out comments made by the Vice-President of the Commission Frank Timmermans. The government even called Timmermans to stop with his comments. ${ }^{36}$

The lack of good faith on the government's part is further corroborated by its claim that it took into account a number of recommendations made by the Venice Commission, while simultaneously publicly attacking its recommendations for extreme one-sidedness. ${ }^{37}$

\subsection{The Third Recommendation}

The Commission adopted a third Recommendation complementary to the first two on 26 July $2017 . .^{38}$ The scope of the Recommendation considerably widened beyond the changes to the CT as a reaction to further proposed changes to the judiciary.

The Recommendation starts by observing that none of the recommended actions regarding the CT and the constitutional review had been complied with. That the three 'December' judges still carry out their function, that the President was replaced by the acting President Julia Przyłębska, that the judgments from 9 March 2016 onwards had not been published, and that the specified laws had not been subject to constitutional review. The Polish government did not stop at capturing the CT. It presented a set of new laws and new amendments threatening the independence of the judiciary, including the ordinary judiciary and the Supreme court.

The new law on Ordinary Court Organization granted the Minister of Justice the power to appoint and dismiss court presidents without being bound by concrete criteria. The court presidents have a double role of being the court manager and a judge plus they have strong managerial position vis-à-vis other judges. ${ }^{39}$ The potential dismissal

36 MFA statement on the Polish government's response to Commission Recommendation of 27.7.2016. Ministerstwo Spraw Zagranicznych [online]. [cit. 18.2.2020]. Available at: https://www.msz.gov.pl/en/p/ msz_en/news/mfa_statement_on_the_polish_government_s_response_to_commission_recommendation_of_27_07_2016

37 Minister Waszczykowski: the Venice Commission report is extremely one-sided, PAP dispatch from 14 October 2016. Ministerstwo Spraw Zagranicznych [online]. [cit. 18. 2. 2020]. Available at: https://www. msz.gov.pl/en/news/they_wrote_about_us/minister_waszczykowski_the_venice_commission_ report_is_extremely_one_sided_pap_dispatch_from_14_october_2016

38 Commission Recommendation (EU) 2017/1520 regarding the rule of law in Poland complementary to Recommendation (EU) 2016/1374 and (EU) 2017/146. European Commission [online]. 2017.

39 For a more extensive debate on the role of the court presidents, see KOSAR, D. and A. BLISA. Court Presidents: The Missing Piece in the Puzzle of Judicial Governance. German Law Journal, 2018, no. 7. Available at: https://is.muni.cz/publication/1479897/en/Court-Presidents-The-Missing-Piece-in-thePuzzle-of-Judicial-Governance/Kosar-Blisa [cit. 11. 3. 2020]. 
or reappointment could threaten their and other judges' independence. ${ }^{40}$ The new laws allowed the assistant judges, who do not have the same guarantees of independence as the ordinary judges, to act as single judges in district courts.

The National Council of the Judiciary ('KRS') did not go unchanged either as the Polish government considered mainly its judicial component as an obstacle to its reform. The KRS is a body of judicial self-governance that safeguards judicial independence and has an impact on individual judges as regards their promotion, transfer, disciplinary proceedings, dismissal, or early retirement. Before the amendment and according to the Constitution, out of the 25 members KRS, 15 judges-members were appointed by their peers.

The amendment of the law on the KRS stipulates that the 15 judges-members would be chosen and potentially reappointed by Sejm. In total, 23 out of 25 members of the KRS would be elected either by Sejm or Senate. That would have significantly hiked the influence of Sejm over the KRS and indirectly threatened the independence of judges. Moreover, the mandates of all the current judges-members would be prematurely terminated despite the length of the mandate being Constitutionally guaranteed. ${ }^{41}$ The Recommendation also addressed the internal restructuring of the KRS, and it pointed out the potential unconstitutionality of the amendment and recalled the unavailability of effective constitutional review. ${ }^{42}$

The last batch of proposed changes involved the Supreme court. The major concern of the Commission was the forcible termination of mandates and retirement of all judges of the SC the day following the entry of force of the new law on the SC. They could be possibly reappointed upon a decision of the President of the Republic on the basis of an indication of the Minister of Justice and a consultation with the KRS.

The retirement age of the SC would be lowered from 67 to 65 years for male judges and from 67 to 60 years for female judges. The Minister of Justice would gain the power to extend the mandate upon a request from an individual judge, thus increasing the influence of the Minister could exert over individual judges and threatening their independence. The Recommendation concluded that the combination of lowering the retirement age with the power of the Minister to extend the mandates undermines the principle of irremovability of judges, which is a crucial element of independence of the judiciary.

The Recommendation also addressed the changes made to the disciplinary proceedings against judges. A new disciplinary chamber was to be established, the disciplinary proceedings could be initiated by the Minister of Justice, plus their role would be further

40 Paras. 18-23.

41 SADURSKI, 2019, op. cit., pp. 99-102.

42 Commission Recommendation (EU) 2017/1520 regarding the rule of law in Poland complementary to Recommendation (EU) 2016/1374 and (EU) 2017/146. European Commission [online]. 2017, paras 24-30. 
strengthened in the proceedings. The changes to the disciplinary proceedings would further undermine the independence of judges.

The Commission also pointed out the fast tracking and lack of discussion during the legislative process.

On top of the recommended actions that had been made in the first two Recommendations, the Commission recommended that the Polish authorities in the 1-month limit:

- Ensure that the laws on the KRS, on Ordinary Court Organization and on the $\mathrm{SC}$ do not enter into force and that the law on the KRS complies with the Constitution and the European standards,

- Refrain from any measures interfering with the mandate of the SC judges,

- Ensure that any justice reform upholds the rule of law and complies with the EU standards on judicial independence,

- Refrain from actions and public statements that could undermine the legitimacy and efficiency of the CT, the SC, the ordinary courts, and the judiciary as a whole. ${ }^{43}$

The Polish government published a statement the day the third recommendation was issued. The government accused the Commission of using 'a language of ultimatums', calling the non-binding recommendation as a premature 'interference with the legislative process in Poland' because the reform of the Polish judiciary had yet not been carried out. The government attacked the Commission for its partiality, lack of understanding of the fundamental and substantive aspects of the reform, and its lack of competence. ${ }^{44}$ The government asked for further clarification, ${ }^{45}$ only to attack the Commission for its absence of willingness to engage in a dialogue and insufficient concreteness of its reply. ${ }^{46}$ After asking for one more clarification, the government corroborated its claims about the lack of a constructive dialogue by pointing out that Timmermans' position coincided with the stance of the Polish opposition. ${ }^{47}$

43 Ibid.

44 MFA statement following the European Commission's Recommendation of 26 July 2017 regarding the rule of law in Poland. Ministerstwo Spraw Zagranicznych [online]. [cit. 18. 2. 2020]. Available at: https:// www.msz.gov.pl/en/news/mfa_statement_following_the_european_commission_s_recommendation_ of_26_july_2017_regarding_the_rule_of_law_in_poland_

45 Letter of Polish Foreign Minister to European Commission's First Vice-President. Ministerstwo Spraw Zagranicznych [online]. [cit. 18.2.2020]. Available at: https://www.msz.gov.pl/en/news/ letter_of_polish_foreign_minister_to_european_commission_s_first_vice_president_

46 MFA communique following reply from Commission First Vice-President to Polish Foreign Minister's letter. Ministerstwo Spraw Zagranicznych [online]. [cit. 18.2.2020]. Available at: https://www.

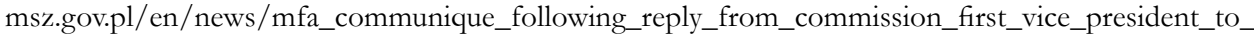
polish_foreign_minister_s_letter_1

47 Communique following European Commission reply to MFA letter. Ministerstwo Spraw Zagranicznych [online]. [cit. 18.2.2020]. Available at: https://www.msz.gov.pl/en/news/ communique_following_european_commission_reply_to_mfa_letter 
The accusation of premature interference is quite ironical in the perspective of the Framework being a preventative mechanism, not one aimed at resolving already inflicted damage to the rule of law. It is only logical that the Commission would intervene before any harmful changes of the judiciary are implemented. The rest of the response only reflects the paranoia and lack of good will at the side of the Polish government.

\subsection{The Fourth Recommendation}

The last Recommendation was issued on 20 December 2017 following a number of legal changes of the judiciary. ${ }^{48}$ The Polish government went through with several changes despite the previous recommendations. In the new law on the SC from December 2017, the retirement age of the SC judges was lowered to $65,{ }^{49}$ forcibly retiring around $37 \%$ judges. The forced retirement would entail the premature termination of the mandate of the SC President. The new law gave power to the President of the Republic upon request of the judges to prolong their mandate. The President was not bound by any criteria, nor timeframe. The early retirement, the prospect of request for prolongation of the mandate, the implied far-reaching personal recomposition in combination with the changes to the KRS threatened judicial independence and raised the issues of unconstitutionality. ${ }^{50}$

The new law also introduced an extraordinary appeal procedure. The SC could review any decision from the past 20 years delivered by a Polish court, thus undermining the principle of legal certainty, a key component principle of the rule of law under the Framework. The grounds for the appeal were indeed very broad. ${ }^{51}$ The law also amended the disciplinary procedure.

The second batch of criticism was addressed against the changes made to the KRS. The Polish government went through the changes, prematurely terminated mandates of all the judges-members and changed the appointment procedure so that the judges-members would be appointed by Sejm en bloc. Again, concerns regarding judicial independence and the constitutionality of the changes were raised. ${ }^{52}$

48 Commission Recommendation (EU) 2018/103 regarding the rule of law in Poland complementary to Recommendation (EU) 2016/1374, (EU) 2017/146 and (EU) 2017/1520. European Commission [online]. 2017.

49 The first proposal contained an unequal retirement age of female and male SC judges. The government bent to the pressure and equalized it to 65. SADURSKI, 2019, op. cit., p. 222.

50 Commission Recommendation (EU) 2018/103 regarding the rule of law in Poland complementary to Recommendation (EU) 2016/1374, (EU) 2017/146 and (EU) 2017/1520. European Commission [online]. 2017, paras. 5-17.

51 SADURSKI, 2019, op. cit., p. 114.

52 Commission Recommendation (EU) 2018/103 regarding the rule of law in Poland complementary to Recommendation (EU) 2016/1374, (EU) 2017/146 and (EU) 2017/1520. European Commission [online]. 2017, paras. 22-35. 
The Commission mainly reiterated its recommended actions from the previous Recommendations and made 2 novel recommended actions concerning the new laws. The Polish authorities should in three months:

- Ensure amendment of the law on the SC so that the lowered retirement age does not apply, the discretionary power of the President of the Republic to prolong mandates is removed, the extraordinary appeal procedure is removed,

- Ensure that mandates of the judges-members of the KRS are not prematurely terminated and that they are appointed by their peers. ${ }^{53}$

The government did not respond to the last Recommendation as it saved up its arguments for the response to the reasoned proposal..$^{54}$

\subsection{The reasoned proposal}

The last Recommendation was issued along with the reasoned proposal under Art. 7(1) TEU. ${ }^{55}$ The reasoned proposal is required to trigger the preventative mechanism of Art. 7 TEU. The proposal must be 'reasoned', i.e. it must contain information and the basis for the conclusion reached by the reasoned proposal.

The reasoned proposal lodged by the Commission heavily builds on the first three Recommendations. The explanatory memorandum attached to the proposal explicitly refers to the Recommendations for more detailed information on the development in Poland as the proposal contains 'an overview of the main developments'. ${ }^{56}$

The proposal contains an implicit evaluation and a brief evaluation of the effectiveness of the preceding dialogue under the Framework. The reasoned proposal is presented as 'a new phase of dialogue formally involving the European Parliament and the Council' after that two years of dialogue with Poland had not led to results and had not prevented further deterioration of the situation. ${ }^{57}$ To me, calling a potential determination of 'a clear risk of a serious breach of the rule of law' as a new phase of dialogue is a major understatement of the gravity of the situation.

While the reasoned proposal admits the ineffectiveness of the prior dialogue, it also submits that all the Recommendations played an important role in supplementing

53 Ibid., paras. 22-35.

54 MFA statement on the European Commission's decision to launch the disciplinary process against Poland laid out in Article 7 of the TEU. Ministerstwo Spraw Zagranicznych [online]. [cit. 18. 2. 2020]. Available at: https://www.msz.gov.pl/en/p/msz_en/news/mfa_statement_on_the_european_commission_s_decision_to_launch_the_disciplinary_process_against_poland_laid_out_in_article_7_of_the_teu

55 Proposal for a Council decision on the determination of a clear risk of a serious breach by the Republic of Poland of the rule of law $\operatorname{COM}(2017) 835$ final. 2017. European Commission [online]. [cit. 13. 2. 2020]. Available at: https://eur-lex.europa.eu/legal-content/EN/ TXT/?qid=1555065725694\&uri=CELEX\%3A52017PC0835

56 Explanatory memorandum of the Proposal, para. 6.

57 Explanatory memorandum of the Proposal, para. 184. 
the Commission with sufficient information to issue a reasoned proposal under Art. 7(1) TEU. Moreover, the failure to comply with the Recommendations is used as a justification for the proposal. ${ }^{58}$ It is important to keep in mind that the Commission admits that the Framework failed all its roles, but the information-gathering role.

\subsection{The future of the Framework}

The last two documents in which the Recommendation figures are the 2019 Commissions communications on the future of the rule of law within the Union ${ }^{59}$ and the blueprint for action. ${ }^{60}$

The first document presents a self-reflection on the numerous rule of law instruments the EU wields and on their usage. When shifting the focus to the future, the document discusses possibly promotion, prevention, and enforcement of the value of the rule of law. The communication again stresses the importance of establishing an effective dialogue as a solution to the rule of law crises and Framework's key role in creating the knowledge base in further action from the Union.

The communication ponders several potential improvements: a greater involvement of other institutions (the EP, the Council, the Venice Commission, the CoE), underpinning the dialogue with specific action plans and technical support, and strengthening consequences if a Member state fails to remedy the situation. The document concludes by inviting relevant stakeholders for a debate.

The blueprint for action is the follow up on the first document. It builds on the debate that had been led in the meantime. The Commission would in the future involve other EU institutions more regularly when implementing the Rule of Law Framework. ${ }^{61}$ Moreover, the Framework would come with clearer procedures and timelines. ${ }^{62}$ The document does not specify what exactly does that mean. Lastly, perhaps more implicitly, the Commission vowed that the EU action would be objective, proportionate, and non-discriminatory. ${ }^{63}$

58 Proposal for a Council decision on the determination of a clear risk of a serious breach by the Republic of Poland of the rule of law COM(2017) 835 final. European Commission [online]. 2017, para. 31 [cit. 13.2. 2020].

59 "Further strenghtening the Rule of Law within the Union: State of play and possible next steps" (Communication from the commission to the European Parliament, the European Council, and the Council) COM(2019) 163 final. European Commission [online]. 2019. Available at: https://eur-lex.europa. eu/legal-content/EN/TXT/?uri=CELEX\%3A52019DC0163

60 "Strenghtening the Rule of Law within the Union: A blueprint for action" (Communication from the commission to the European Parliament, the European Council, and the Council) COM(2019) 343 final. European Commission [online]. 2019, p. 1 [cit. 22. 2. 2020].

61 Ibid., p. 50.

62 Ibid., p. 14.

63 Ibid., p. 3. 


\section{Case-study: Poland}

In this part, I critically assess whether the Framework was effective in achieving its goals. I argue that the Framework aimed at achieving three objectives: eliciting a change of national law or practice concerning rule of law, gathering information related to rule of law for future use, and mobilizing internal actors other than the government encroaching upon rule of law. Keeping in mind that the Framework is a case of soft-law mechanism with weakened dimension of obligation and precision, ${ }^{64}$ the goal of eliciting a change of law or of practice (or preventing such change) flows from the Framework's text itself (see Part 1). The goal of gathering information follows from its ensuing implementation (see Part 3.5) and the official debate surrounding it (Part 3.6). The effectiveness of the Framework will now be assessed against the background of these three goals.

The first goal of eliciting change in law and in practice could be understood in two terms. First, the objective could be understood in broader terms as aiming at eliciting a profound change of legal culture and adoption of new patterns of political behaviour in Member states. Second, the objective could be understood in more limited terms as aiming to force certain legislative changes in Member states. ${ }^{65}$ Since the Framework is a soft-law mechanism and the Recommendations have always identified concrete issues, its effectiveness will be measured against the more limited understanding of the objective.

Hence in terms of the first objective, the effectiveness of the Framework is assessed as the impact of the Framework upon the issues identified in the implementing recommendations. For more clarity, I created a table of the chronological development of the recommended actions made by the Commission addressed to Poland.

Table 1: The chronological overview of the issues identified sorted by the recommendations ( $\mathrm{x}$ stands for non-implementation and new signals the issue appearing for the first time).

\begin{tabular}{|l|c|c|c|c|}
\hline Issue & 1st & 2nd & 3rd & 4th \\
\hline $\begin{array}{l}\text { full implementation of 3 and 9 December 2015 } \\
\text { CT judgments (three 'October' judges can take up their } \\
\text { post, while three 'December' judges cannot) }\end{array}$ & new & $\mathrm{x}$ & $\mathrm{x}$ & $\mathrm{x}$ \\
$\begin{array}{l}\text { publish and implement the CT judgments from 9 March } \\
\text { onwards }\end{array}$ & new & $\mathrm{x}$ & $\mathrm{x}$ & $\mathrm{x}$ \\
$\begin{array}{l}\text { any reform of the Law on the CT respects the case-law } \\
\text { of the CT }\end{array}$ & new & $\mathrm{x}$ & $\mathrm{x}$ & $\mathrm{x}$ \\
\hline
\end{tabular}

64 ABBOTT, K. W. and D. SNIDAL. Hard and Soft Law in International Governance. International Organization, 2000, no. 3, p. 422.

65 GOLDNER LANG, I. The Rule of Law, the Force of Law and the Power of Money in the EU. Rochester, NY: Social Science Research Network, 2020. Available at: https://papers.ssrn.com/abstract=3545940 [cit. 20. 12. 2020]. 


\begin{tabular}{|c|c|c|c|c|}
\hline Issue & 1st & 2nd & 3 rd & 4th \\
\hline the effectiveness of the CT is not undermined & new & $\mathrm{x}$ & $\mathrm{x}$ & $\mathrm{x}$ \\
\hline $\begin{array}{l}\text { the CT can review the compatibility of the new law } \\
\text { on the CT }\end{array}$ & new & $\mathrm{x}$ & $\mathrm{x}$ & $\mathrm{x}$ \\
\hline $\begin{array}{l}\text { refrain from actions and public statements that could } \\
\text { undermine the legitimacy and efficiency of the CT }\end{array}$ & new & $\mathrm{x}$ & $\mathrm{x}$ & $\mathrm{x}$ \\
\hline $\begin{array}{l}\text { the CT can review the Law on the status } \\
\text { of judges, on rganization and proceedings and } \\
\text { the Implementing law }\end{array}$ & & new & $\mathrm{x}$ & $\mathrm{x}$ \\
\hline $\begin{array}{l}\text { no appointment of the President of the CT takes place } \\
\text { as long as the judgments have not been fully published } \\
\text { and implemented and as long the October judges } \\
\text { haven't taken up their function }\end{array}$ & new & $\mathrm{x}$ & $\mathrm{x}$ & \\
\hline $\begin{array}{l}\text { ensure that the acting President does not replace the } \\
\text { President of the CT }\end{array}$ & & new & $\mathrm{x}$ & $\mathrm{x}$ \\
\hline $\begin{array}{l}\text { the law on the KRS, Ordinary Courts Organization, } \\
\text { on the SC do not enter into force, the law on the KRS } \\
\text { is withdrawn/amended not to violate the Constitution } \\
\text { and European standards }\end{array}$ & new & $\mathrm{x}$ & & \\
\hline $\begin{array}{l}\text { any justice reforms respekts the rule of law and } \\
\text { complies with EU law and European standards, }\end{array}$ & & & new & $\mathrm{x}$ \\
\hline $\begin{array}{l}\text { the law on the } \mathrm{SC} \text { is amended not to apply lowered } \\
\text { retirement age, the discretionary power of the PotR } \\
\text { to prolong the mandate is removed, the extraordinary } \\
\text { appeal procedure is removed }\end{array}$ & new & & & \\
\hline $\begin{array}{l}\text { the law on the KRS is amended so that the mandate } \\
\text { of judge-members it not terminated and new } \\
\text { appointement regime removed }\end{array}$ & & & new & \\
\hline $\begin{array}{l}\text { refrain from actions and public statements that could } \\
\text { undermine the legitimacy of the CT, ordinary courts } \\
\text { and the judiciary as a whole }\end{array}$ & & & new & \\
\hline Time limit & $\begin{array}{c}3 \\
\text { months }\end{array}$ & $\begin{array}{c}2 \\
\text { months }\end{array}$ & $\begin{array}{c}1 \\
\text { month }\end{array}$ & $\begin{array}{c}3 \\
\text { months }\end{array}$ \\
\hline
\end{tabular}

Source: Author

The table quite clearly corroborates the claim of the ineffectiveness of the Framework with regard to changing the course of action of the rule of law backsliding in Poland. The ineffectiveness of the Framework in terms of the first goal can be further illustrated on the reaction of the Polish government to the individual recommendations. In my view, they also prove that a more systemic and profound change is unlikely to result from the Framework. 
The reactions of the Polish government only show its unwillingness to engage in a constructive dialogue with the Commission. The government failed to substantiate its accusations and arguments, and its rhetoric grew more aggressive and harsher. A change of law or of practice could not be expected by an actor, the government, using such harsh rhetoric and disregard for good faith dialogue. It only corroborates Kochenov and Pech's conclusion that a government intentionally undermining the rule of law and unwilling to enter into a dialogue in good faith cannot be expected to change its practice under a dialogue-based mechanism.

In terms of the second goal, I argue that the Framework was a success. The information gathered in the recommendations was put into practice in the latter reasoned proposal (see Part 3.5). The downside of the information-gathering function is that it only works with regard to the Member state that is already on track to rule of law backsliding. The issue of potential discrimination and partiality may be in future resolved by the upcoming Annual Rule of Law Cycle, which applies to all Member States. The implementation of the Cycle, in turn, undermines the information gathering purpose of the Framework as it would be better served by a different tool.

In terms of the third goal, it hard to track down the impact of the Framework upon the internal actors. The judiciary reforms have repeatedly sparked massive protests, for example, massive protests against the reforms effectively capturing the ordinary judiciary and the KRS. ${ }^{66}$ The Framework's most tangible appearance is the joint Open Letter to the College of Commissioners regarding the situation in Poland sent by a plethora of international and Polish NGOs. According to the signatory NGOs, the Framework was a welcome addition to the EU rule of law toolbox, and the NGOs expressed a fondness of the Commissions follow up Art. 7 TEU activation. Yet, the NGOs remained concerned about the development of rule of law backsliding in Poland. ${ }^{67}$

The signing NGOs include NGOs focused on LGBT+ rights (Stowarzyszenie Queerowy Maj), on human rights (Helsińska Fundacja Praw Człowieka), or civic society (Sieć Obywatelska Watchdog Polska). Hence the Framework reached out at least to some segments of the non-legal community. For a legal tool to reach the non-legal community can, in my eyes, be considered a success.

\section{Conclusion}

The Rule of Law Framework was the centrepiece of this article. So far, it has escaped close attention, and the majority of it came before or around its first implementation.

66 SADURSKI, 2019, op. cit., p. 99.

67 Open Letter to the College of Commissioners regarding the situation in Poland. Amnesty International and other NGOs [online]. 2017 [cit. 26. 11. 2020]. Available at: https://www.amnesty.org/download/ Documents/EUR3756842017ENGLISH.PDF 
Around six years have elapsed between now and the Framework's establishment. That is more than sufficient time to analyze its effectiveness. Building on the detailed and thorough analysis carried out in this article, it is now possible to conclude that the Framework was only effective in its information-gathering function. It failed in eliciting almost any change in law or the political practice of a Member state.

As the rule of law situation in Poland and Hungary is arguably worsening, the need to evaluate the effectiveness of EU law's current mechanisms is even more pressing to improve them, building upon the experience. The Commission is well aware of the need to evaluate and potentially change its approach. That's why it at the beginning of 2019 opened a discussion on the current state and the future of the rule of law within the EU. The question of whether legal instruments can solve the rule of law crises across the Member states underlies the whole discussion and cannot be avoided in the future.

What is perhaps even more striking is the Commission's lack of self-reflection and overreliance on soft-law dialogue-based mechanisms, given their apparent ineffectiveness. Their ineffectiveness has been admitted by the Commission itself (see above) and pointed out by scholars. ${ }^{68}$ Information gathering is the only role Framework. Similarly, the Justice scoreboard has succesfully played, which cannot in itself warrant the expectation that they will halt the rule of law backsliding. As Kochenov and Bard point out, the invention of new soft-law procedures cannot justify the EU's inactivity and engagement with other mechanisms. ${ }^{69}$

68 KOCHENOV, BARD, 2018, op. cit., pp. 16-17.

69 Ibid., p. 16. 